\title{
New image analysis tool to study biomass and morphotypes of three major bacterioplankton groups in an alpine lake
}

\author{
Thomas Posch ${ }^{1, *}$, Josef Franzoi ${ }^{2}$, Martin Prader $^{2}$, Michaela Maria Salcher $^{1}$ \\ ${ }^{1}$ Department of Limnology, Institute of Plant Biology, University of Zürich, Seestrasse 187, 8802 Kilchberg, Switzerland \\ ${ }^{2}$ Institute of Ecology, University of Innsbruck, Technikerstraße 25, 6020 Innsbruck, Austria
}

\begin{abstract}
We present an image analysis routine to determine the contribution of distinct morphotypes to the total abundance and biomass (carbon) of freshwater bacterioplankton and to the fraction of cells detected by fluorescence in situ hybridization via catalyzed reporter deposition (CARD-FISH). The method was tested on bacterial assemblages from an alpine lake (Piburger See, Austria) at characteristic time points during the limnological year. Although on average $51 \%$ of $4^{\prime}, 6^{\prime}$-diamidino-2-phenylindole (DAPI)-stained objects were hybridized with the oligonucleotide probe EUB I-III, we detected on average $80 \%$ of total biomass determined from DAPI staining. The assemblage was numerically dominated by cocci and rods $<0.6 \mu \mathrm{m}$ (mean cell volume $=0.024 \mu^{3}$ ). Only a minor part of these morphotypes could be hybridized (18 and 50\%, respectively). In contrast, larger rods $\left(0.087 \mu^{3}\right)$, cocci $\left(0.155 \mu^{3}\right)$ and vibrio-shaped cells $\left(0.073 \mu^{3}\right)$ showed much higher probabilities to be detected by CARD-FISH. These morphotypes per se formed the highest contribution to total biomass, which explained the high detection efficiency of biomass with CARD-FISH. In addition, we determined the seasonal dynamics of morphotype distributions within 3 distinct phylogenetic lineages. Actinobacteria were predominately small rods and cocci, whereas bacteria from the Cytophaga-Flavobacterium-Bacteroides group formed mainly large rods, cocci and filaments. Betaproteobacteria showed the highest morphological variability. Within all lineages, distinct spatio-temporal dynamics of dominant morphotypes were observed. Thus, the approach presented here will allow for more detailed studies of the amount of carbon bound by different bacterial taxa. This is of relevance as distinct lineages can contribute much more to total bacterial biomass than to total bacterioplankton abundance.
\end{abstract}

KEY WORDS: Bacterial biomass - Bacterial morphotype · CARD-FISH $\cdot$ DAPI $\cdot$ Image analysis

Resale or republication not permitted without written consent of the publisher

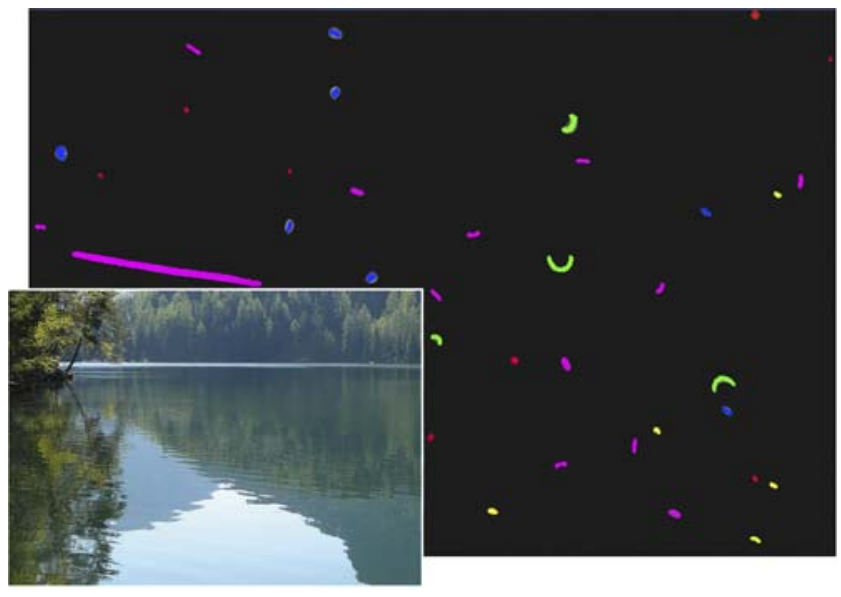

Bacterial morphotypes detected by the newly developed image analysis procedure, labelled by colored overlays. Insert: Study site Piburger See, Austria.

Photo: T. Posch \& M. M. Salcher

\section{INTRODUCTION}

Planktonic freshwater bacteria differ in their phenotypes, genotypes and physiological properties. It is a challenging task to develop methods at the single cell level that simultaneously provide information on more than one of these bacterial characteristics. The combination of fluorescence in situ hybridization (FISH) and DNA staining with the fluorochrome DAPI $\left(4^{\prime}, 6^{\prime}-\right.$ diamidino-2-phenylindole) has to be regarded as one highlight in this context (Hicks et al. 1992). A further improvement of FISH via combination with microautoradiography techniques indeed provides information on the taxonomic affiliation, the morphotype and activity patterns (Lee et al. 1999). Although FISH enables the simultaneous analysis of the morpho- and genotype, most studies have only focused on the numerical 
importance of distinct freshwater bacterial lineages, i.e. on cell numbers or on percentages of the total assemblage (Bouvier \& del Giorgio 2003, Wu et al. 2006, see also Appendix 1, available as Supplementary Material at: www.int-res.com/articles/suppl/ a054p113_app.pdf), rather than on biomasses (Pernthaler et al. 1997, Cottrell \& Kirchman 2003, Yokokawa et al. 2004) or biovolumes (Kirchman et al. 2003). In contrast to abundance, the unit biomass (e.g. carbon content) allows for a direct comparison of energy and elements bound by different compartments within a trophic cascade. More recently, Posch et al. (2007) showed that selective grazing by protists can affect the biomass of bacterial clades to a much higher degree than their abundance.

Many investigations using the oligonucleotide probes EUB338 or EUB I-III for the detection of Bacteria (Daims et al. 1999) share one characteristic observation: detection efficiencies of bacteria, hybridized with these probes, do not always reach $100 \%$ of DAPIstainable objects (see Appendix 1). Most likely, this 'underestimation' is not due to methodological problems of the FISH method itself (Wagner et al. 2003, Aman \& Fuchs 2008). In contrast, DAPI — as the typical reference dye for FISH - may also stain viruses (Bettarel et al. 2000) or even detrital and sub-micrometer particles, thus potentially leading to imprecise estimates of bacterial numbers, i.e. an overestimation of total bacterial abundance.

In the present study, we highlight that hybridization with probe EUB I-III allows the detection of a large fraction of freshwater bacterioplankton carbon content (= biomass), even if the hybridization efficiency is not $100 \%$ of all DAPI-stainable objects. We present an image analysis procedure to discriminate between different bacterial morphotypes and to assess their contribution to total bacterial numbers and biomasses. In a second step, we analyzed which of these morphotypes were detected by CARD-FISH and evaluated their contribution to the total assemblage. By applying 3 specific oligonucleotide probes, we further linked the information on morphotypes with a taxonomic affiliation. We argue that sizing of bacteria and the use of volume to carbon conversion factors seems to be a promising approach to quantify the carbon contents of different bacterial populations within freshwater microbial communities.

\section{MATERIALS AND METHODS}

Study site and sampling. Piburger See is a dimictic, oligo-mesotrophic lake in the Austrian Alps (913 m above sea level). In May 2005, shortly after the phytoplankton spring bloom, samples were taken with a 51
Schindler sampler at $3 \mathrm{~m}$ intervals from 0 to $24 \mathrm{~m}$ depth (maximum depth $=24.6 \mathrm{~m}$ ). On 7 dates between June 2005 and February 2006, we took samples at 4 selected depths $(3,9,18$, and $24 \mathrm{~m})$ to follow the seasonal patterns of hybridized bacteria. We chose the depth layers to sample the epilimnion (3 $\mathrm{m})$, the metalimnion $(9 \mathrm{~m})$ and the hypolimnion (18 and $24 \mathrm{~m}$ ) during summer stratification. The same depth layers were also sampled during mixis and winter stratification. Physical and chemical data on the lake during the investigation period are presented in Salcher et al. (2008).

Total abundance of DAPI-stainable objects. Samples of $40 \mathrm{ml}$ were fixed with $0.2 \mu \mathrm{m}$ pre-filtered formaldehyde (3\% final conc.) and processed within $1 \mathrm{wk}$. To avoid cell losses during this short storage time, samples were kept at a temperature of $+4^{\circ} \mathrm{C}$ in the dark. Subsamples (2 to $3 \mathrm{ml}$ ) were stained with DAPI (4 $\mathrm{g} \mathrm{m} \mathrm{m}^{-1}$ final conc.; staining time: $7 \mathrm{~min}$; Porter \& Feig 1980) and filtered onto black polycarbonate filters (0.22 $\mu \mathrm{m}$ pore size, Osmonics). We used a Zeiss Axioplan microscope with an optovar for additional magnification $(1.25,1.6,2.0$ and $2.5 \times)$ and a Zeiss 01 filter set (BP 365, FT 395, LP 397) for UV-excitation. We counted 700 to 1000 DAPI-stained particles per subsample at a magnification of $2000 \times$.

CARD-FISH. Samples of $10 \mathrm{ml}$ were fixed with paraformaldehyde ( $2 \%$ final conc., adjusted to $\mathrm{pH} 7.4$ ). Within $2 \mathrm{~h}$ after fixation, samples were filtered onto white polycarbonate filters (Millipore, Type GTTP, $0.2 \mu \mathrm{m}$ pore size, $47 \mathrm{~mm}$ diameter) and stored at $-20^{\circ} \mathrm{C}$ until further processing. CARD-FISH was carried out as previously described by Sekar et al. (2003) using the following horseradish peroxidase (HRP)-labeled probes: EUB I-III for Bacteria (Daims et al. 1999), BET42a for Betaproteobacteria (Manz et al. 1992) used in combination with the unlabelled competitor GAM42a, CF319a for members of the CytophagaFlavobacterium-Bacteroides group (Manz et al. 1996), and HGC69a for Actinobacteria (Roller et al. 1994). Signal-amplification was carried out with ALEXA 488 labeled tyramides. Hybridized cells were analyzed at blue excitation (filter set Zeiss 09, BP 450-490, FT 510, LP 515). Multiple variations of lysozyme- and achromopeptidase concentrations as well as hybridization durations (T. Posch unpubl. data) did not result in higher detection efficiencies than reached by applying the standard procedure described in Sekar et al. (2003). Additionally, we tested the probes ALF968, ARCH915 and GAM42a (see Amann \& Fuchs 2008 for references) for selected samples. These bacteria were only present in low abundances and therefore excluded from further analysis.

Image analysis procedure (Figs. $1 \& 2$ ). We used the image analysis software LUCIA G/F (Laboratory Imaging) for the determination of the organisms' dimensions 
and morphotypes (Posch et al. 1997). The system has a user-friendly and simple macro-language, which allowed for an extensive automation of the workflow (Fig. 1, the software macro can be obtained from the authors upon request). Pictures were taken with a Vosskühler $\mathrm{CCD}$ camera (12 bit, resolution $=976 \times$ 756 pixel), with a $100 \times$ objective (Apochromat) and a $1.25 \times$ optovar, resulting in a pixel length of $0.055 \mu \mathrm{m}$ pixel $^{-1}$. LUCIA G/F works with 8 bit images per channel, corresponding to 256 possible gray values per pixel ( $0=$ black, $255=$ white $)$. One image can be composed of up to 3 gray channels (Channels 1 to 3), resulting in a pseudo-color RGB image. Images taken at different excitation wavelengths may not exactly match (due to pixel shift). All modern microscopes are equipped with an electronic filter wheel, ensuring that exactly the same microscopic field is observed after changing the excitation wavelength. Nevertheless, like most other image analysis systems, LUCIA also includes a function to correct for such possible pixel-shifts. We took 2 images from the same field of view: one at UV-excitation for the detection of all DAPI-stainable objects (Channel 1) and a second at blue excitation for the detection of hybridized bacteria within the same microscopic field (Channel 2). First, we detected all cells of the 2 channels, resulting in 2 binary images (see details below). Second, all morphotypes of Channel 1 (DAPIstainable objects) were measured. Binary images of both Channels 1 and 2 were combined by an object-based 'AND' function, thus selecting those DAPI-stainable objects in the binary image of Channel 1 that had a counterpart in the binary image of Channel 2 (hybridized bacteria). This procedure is robust, as it is not important that the objects of Channels 1 and 2 exactly match, i.e. the full DAPI-stained object is accepted even when only parts of its pixel-area have counterparts in Channel 2. Following this, cell sizes and morphometric parameters were measured from Channel 1 again (Fig. 1), i.e. we measured the dimensions of hybridized cells from their DAPI-signal. Using this procedure, we also estimated the contribution (\%) of hybridized

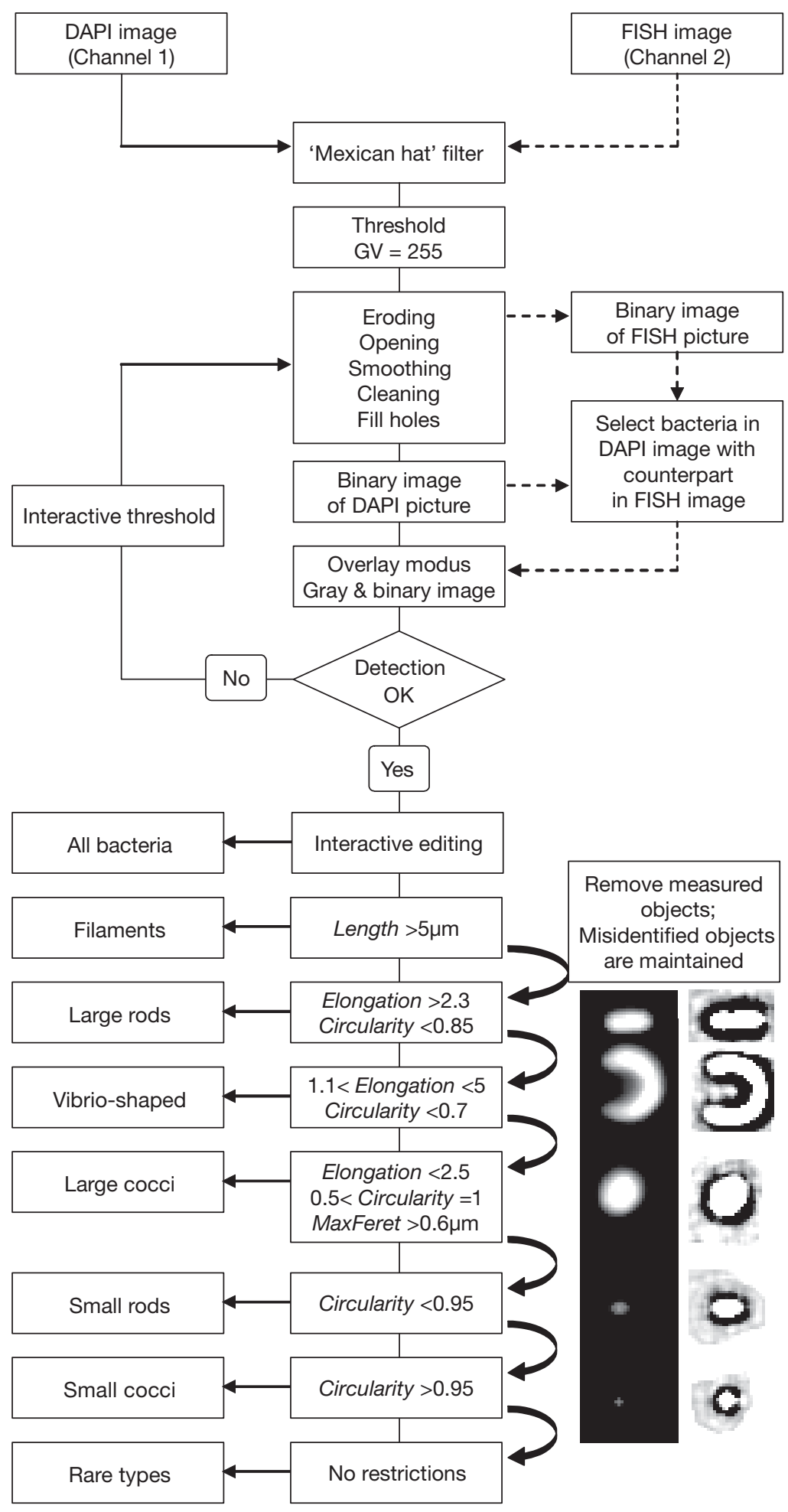

Fig. 1. Image analysis routine for quantifying 7 different morphotypes in the total bacterial assemblage (DAPI image, Channel 1). The contribution of hybridized cells (FISH image, Channel 2) can be assessed by working with double layer images of the same microscopic field. Gray images of 5 morphotypes and the corresponding binary images are shown. See text in 'Materials and methods' and Table 2 for further explanations 
to total DAPI-stainable objects. This procedure works for all major bacterial groups. However, the situation is different for very rare groups with low abundances $(<2 \%$ of DAPI-stainable objects). In that case, the amount of images needed to analyze morphotypes becomes high and leads to a non-random choice of images. For a detailed study of very rare phylotypes, we see the future in fully automated microscopy systems (Pernthaler et al. 2003).

Morphotype detection of total and hybridized bacteria (Fig. 1). We applied a 'Mexican Hat'-type edge detection filter (kernel size $=5 \times 5$ pixel), which equalizes gray values of all pixels within an object to a value of 255 (Pernthaler et al. 1997). A default threshold value of 255 was set for the generation of the binary image. Although the filter works excellently for the detection of even very dim cells, it slightly overestimates the actual cell dimensions (see examples in Table 1). To reduce the size of objects in the binary image, we applied morphological 'eroding', 'opening'

Table 1. Examples of different DAPI-stainable objects (morphotypes). For the calculation of bacterial cell volumes, we selected the adequate length and width (in bold; for further details see text in 'Materials and methods'). Definitions of measured cell dimensions are given in Table 2. The circulating box (see Table 2 for a definition) for the measurement of Feret dimensions is symbolized for the vibrio-shaped morphotype. GIM: grey image; MEX: grey image after the edge detection process ('Mexican hat'); BIN: binary image

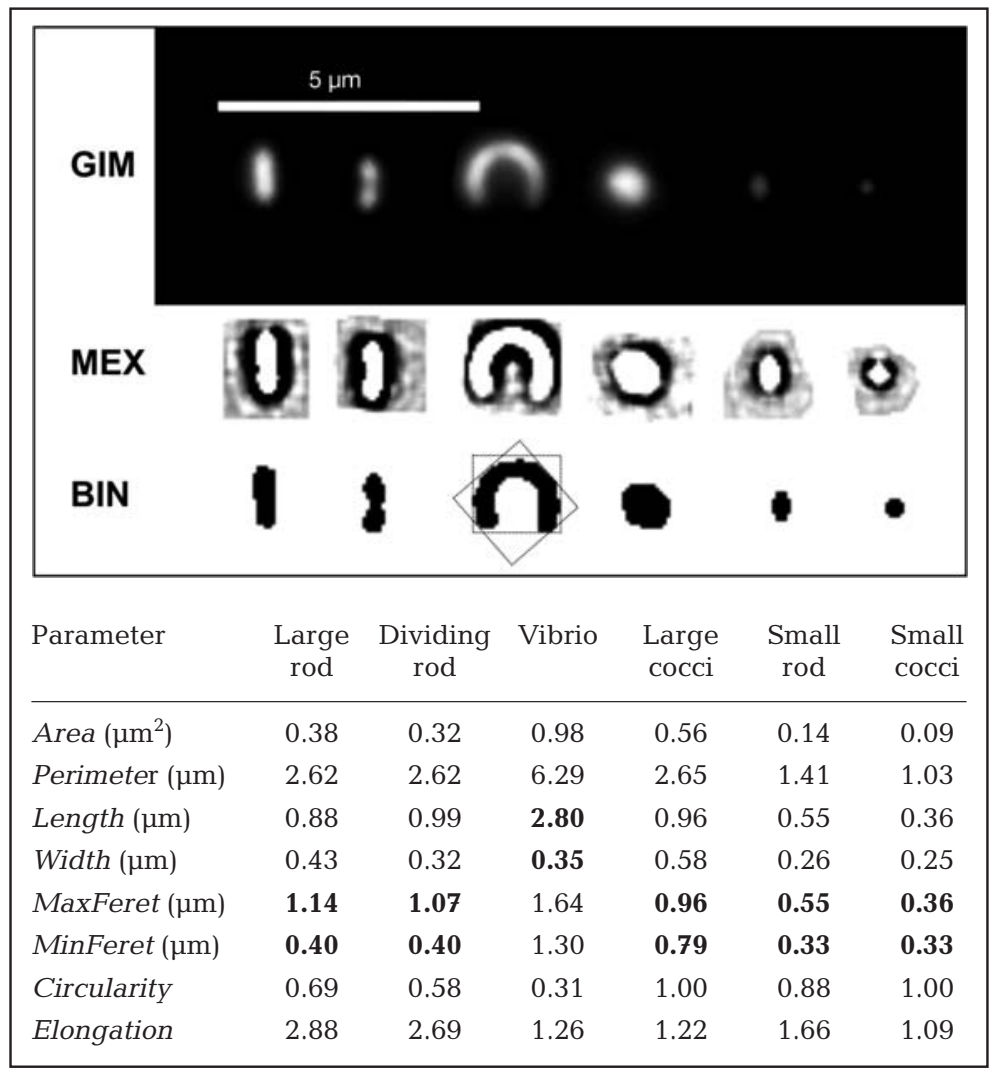

and 'smoothing' procedures. The reliability of this workflow for correct size determinations was tested on differently sized latex beads (Posch et al. 1997). A morphological 'cleaning' of the binary image removed all objects consisting of less than 5 pixels. Prior to measurements, the original gray image was overlaid with the red-colored binary image to ensure the effectiveness of the edge-detection process and of interactively deleting objects other than bacteria (to date, we have no automated process to recognize sub-micrometer detritus particles). This workflow was carried out for both image Channels 1 and 2 .

To distinguish bacterial morphotypes, we applied a sequence of parameter restrictions that allowed the stepwise discrimination of the following morphotypes (Figs. 1 \& 2): filaments, large rods, vibrio-shaped cells, large cocci, small rods, small cocci, and rare irregular morphotypes. Before cells of a distinct morphotype class were measured, we overlaid the original gray image with a binary image presenting solely cells from this class (see Appendix 2, available as Supplementary Material at www.intres.com/articles/suppl/a054p113_app.pdf for examples). By doing this, we were able to interactively delete misclassified objects. The manually removed objects were maintained in the binary image of the next detected class of morphotypes and, therefore, were not lost for the analysis (Figs. 1 \& 2). The analysis was started with the detection of filaments defined as cells with a Length-parameter (see Table 2) larger than $5 \mu \mathrm{m}$. In a next step, larger rod-shaped bacteria were detected. We noticed that DAPI-stained rods from Piburger See had cell widths of 0.26 to $0.33 \mu \mathrm{m}$. The length distribution of all rodshaped bacteria revealed a maximum for small rods at $0.55 \mu \mathrm{m}$ (Fig. 2D). By applying a restriction parameter of Elongation $>2.3$ (Fig. 2A), we obtained large rods with a minimum cell length of approximately $0.65 \mu \mathrm{m}$ (Fig. 2C,D). In addition, we set a second restriction of Circularity $<0.85$ to avoid the detection of large coccoid cells. For the selection of the third morphotype class, namely vibrio-shaped cells, we chose restrictions of Elongation between 1.1 and 5 in combination with Circularity <0.7 (Fig. 2B). Vibrio-shaped cells were characterized by very low circularity values (Fig. 2B, Table 1) as these cells have a large perimeter in comparison to a small area. Most vibrio-shaped cells had Elongation values $<2.3$; however, we 
Table 2. Definition of cell-specific parameters determined with the image analysis software LUCIA G/F (Laboratory imaging). Pr: projection

\begin{tabular}{|c|c|c|}
\hline Parameter & Method of determination & Comment \\
\hline Area $\left(\mu \mathrm{m}^{2}\right)$ & $\Sigma($ pixels within an object $) \times($ pixel area $)$ & Useful for calculation of cell dimensions \\
\hline Perimeter $(\mu \mathrm{m})$ & $0.25 \times \pi \times\left(\operatorname{Pr}_{0}+\operatorname{Pr}_{45}+\operatorname{Pr}_{90}+\operatorname{Pr}_{135}\right)$ & Useful for calculation of cell dimensions \\
\hline Length $(\mu \mathrm{m})$ & $0.25 \times\left(\right.$ Perimeter $+\mid$ Perimeter $^{2}-16 \times$ Area $\left.^{0.5}\right)$ & $\begin{array}{l}\text { Reliable length-estimation for curved cells and } \\
\text { filaments }\end{array}$ \\
\hline Width $(\mu \mathrm{m})$ & Area/Length & $\begin{array}{l}\text { Reliable width-estimation for curved cells and } \\
\text { filaments }\end{array}$ \\
\hline MaxFeret $(\mu \mathrm{m})$ & $\begin{array}{l}\text { Maximum value between tangents circulating at } \\
\text { angle } \alpha=0,10,20, \ldots .180^{\circ} \text { around the object }\end{array}$ & $\begin{array}{l}\text { Reliable length-estimation of straight rods and } \\
\text { coccoid cells }\end{array}$ \\
\hline MinFeret $(\mu \mathrm{m})$ & $\begin{array}{l}\text { Minimum value between tangents circulating at } \\
\text { angle } \alpha=0,10,20, \ldots .180^{\circ} \text { around the object }\end{array}$ & $\begin{array}{l}\text { Reliable width-estimation of straight rods and } \\
\text { coccoid cells }\end{array}$ \\
\hline Elongation & MaxFeret/MinFeret & Allows the detection of rods \\
\hline Circularity & $4 \times \pi \times$ Area $\times$ Perimeter $^{-2}$ & $\begin{array}{l}\text { Value }=1 \text { for circles, }<1 \text { for rods } \\
\text { Vibrios have very low values }\end{array}$ \\
\hline Morphotype Class & $\begin{array}{l}\text { Assigned value between } 1 \text { and } 7 \text {, depending } \\
\text { on morphological characteristics }\end{array}$ & $\begin{array}{l}\text { Characterizes the morphotype } \\
(\text { e.g. filaments }=\text { class } 1 \text {, large rods }=\text { class } 2, \ldots)\end{array}$ \\
\hline Volume $\left(\mu \mathrm{m}^{3}\right)$ & $\begin{array}{l}\left(4 / 3 \times 0.125 \times \text { Width }^{3} \times \pi\right)+ \\
(\text { Length }- \text { Width }) \times\left(0.25 \times \text { Width }^{2} \times \pi\right)\end{array}$ & $\begin{array}{l}\text { Cells are regarded as a cylinder with } \\
2 \text { spherical ends }\end{array}$ \\
\hline $\begin{array}{l}\text { Carbon content } \\
\left(\mathrm{fg} \mathrm{C} \mathrm{cell}^{-1}\right)\end{array}$ & $218 \times$ Volume $^{0.86}$ & $\begin{array}{l}\text { Allometric formula regards the higher carbon } \\
\text { to volume ratio of small cells } \\
\text { (Loferer-Krössbacher et al. 1998) }\end{array}$ \\
\hline
\end{tabular}

set the range of Elongation relatively wide (between 1.1 to 5) because some rare vibrio-shaped cells showed values up to 3 (Fig. 2A). The detection of larger coccoid cells $(>0.6 \mu \mathrm{m})$ was done by a combination of 3 restrictions, i.e. Elongation $<2.5$, Circularity $>0.5$ to $<1$ and MaxFeret $>0.6$ (Fig. 2C). These combined classifiers allowed for an efficient exclusion of rare irregular morphotypes. In the next step, small rods $(<0.6 \mu \mathrm{m})$ were analyzed by the restriction of Circularity $<0.95$, whereas small cocci $(<0.6 \mu \mathrm{m})$ had a Circularity $>0.95$. Finally, we reset all discrimination parameters to look for rare morphotypes, which were occasionally represented by prosthecate cells.

In total, 800 to 2000 DAPI-stainable objects (equivalent to 20-40 images) were measured per sample, resulting in the detection of 100 to 600 hybridized cells on Channel 2. The following parameters were determined for each cell: Area, Perimeter, Length, Width, MaxFeret dimension, MinFeret dimension, Elongation, Circularity, and Morphotype Class (definitions are given in Table 2, see also Fig. 1). For the calculation of bacterial cell volumes, we selected the adequate length and width (Table 1). For cells where Length (calculated from area and perimeter, Table 2) was larger than MaxFeret, we selected the Length and the corresponding Width (Table 1). In all other cases, the Feret dimensions were used and this step was carried out automatically with a Microsoft Excel macro. Mean bacterial cell volumes of all morphotypes were calculated by modeling cells as cylinders with 2 spherical ends (Table 2). This formula can also be applied for spherical cells, as the term 'Length-Width' approaches zero for coccoid cells. Bacterial cell volumes were converted to cellular carbon contents by applying the allometric formula by Loferer-Krössbacher et al. (1998), assuming that carbon corresponds to $50 \%$ of the dry weight (Table 2). Bacterial biomass (in $\mu \mathrm{g} \mathrm{C}^{-1}$ ) was calculated by multiplying cellular carbon content by bacterial abundance (cells $\mathrm{l}^{-1}$ ).

Statistical analyses. Differences in relative abundances of the individual morphotypes within individual phylogenetic groups were established by 2-way ANOVA using a nested factorial design (morphotypes nested within phylogenetic groups). To account for the different data distributions, the relative abundances of morphotypes were arcsine transformed prior to analysis. After establishing significant interactions between the 2 factors, differences between the fractions of morphotypes within each phylogenetic group were separately analyzed by 1-way ANOVA and post-hoc pairwise comparisons (Scheffé method). Statistical analyses were performed using the software SPSS 8.02.

\section{RESULTS}

We observed higher detection efficiencies for bacterial biomass than for abundance with the oligonucleotide probe EUB I-III for all samples taken in May 

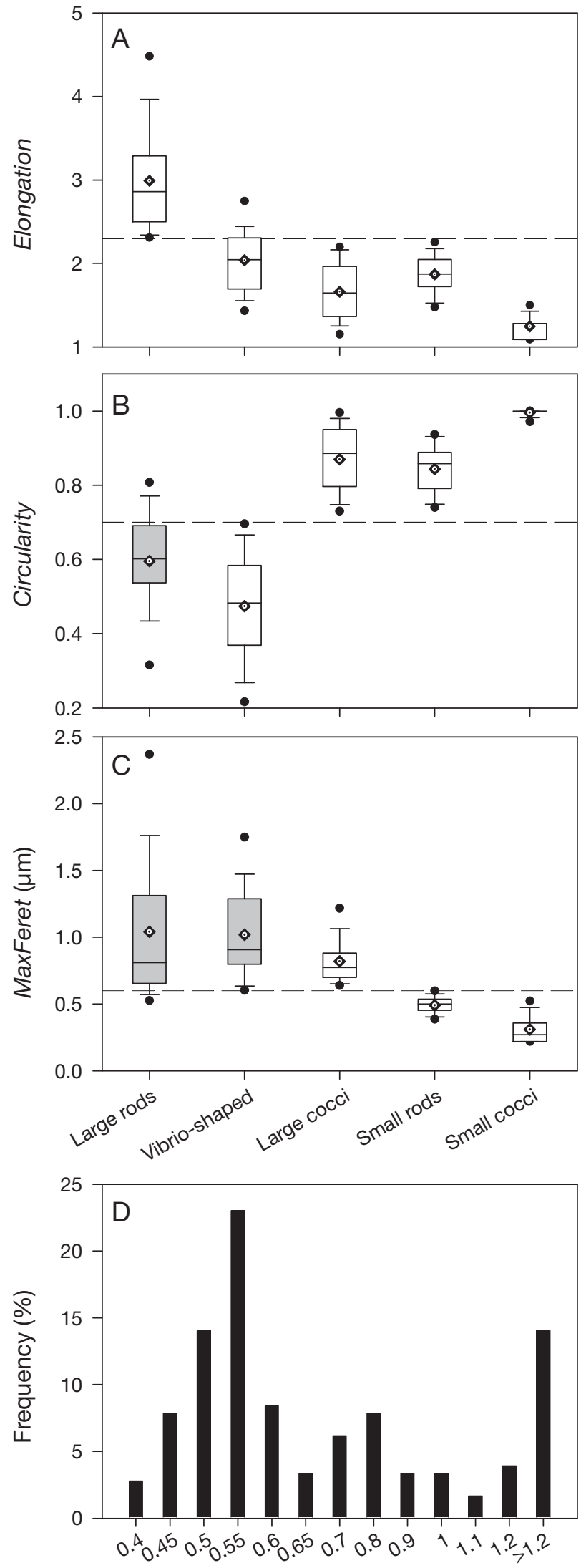

MaxFeret of all rod-shaped bacteria $(\mu \mathrm{m})$
2005 (Fig. 3). Pooled data of total DAPI-stainable objects indicated the following morphotype composition (Fig. 3A): small cocci (50\% of total cells) > large rods $(18 \%)>$ small rods $(17 \%)>$ large cocci $(10 \%)$ $>$ vibrio-shaped bacteria (5\%). Although small cocci numerically dominated, they represented a low contribution to total bacterial biomass $(20 \%)$. Large rods $(28 \%)$ and large cocci $(31 \%)$ formed most of the total biomass (Fig. 3B). The detection efficiency with probe EUB I-III was 35 to $52 \%$ (mean $=43 \%$ ) of total DAPI-stainable objects (Fig. 3C) for samples taken in May 2005. The majority of large morphotypes were hybridized, whereas only $18 \%$ of small cocci were detected (Fig. 4B). The highest fractions of hybridized cells were found within large coccoid (92\%) and vibrio-shaped (80\%) cells (Fig. 4B). Due to the high contribution of larger cell types, up to $87 \%$ of the total biomass could be detected via hybridization (mean = $77 \%$, Fig. 3D). Larger morphotypes generally had higher detection probabilities; however, this did not hold true for small rods (Fig. 4B). Although these morphotypes had cell volumes equivalent to small cocci (Fig. 4A), small rods were more efficiently hybridized. Nevertheless, there was a significantly positive correlation between bacterial cell length class and the fraction of hybridized bacteria contained therein. The best fitting regression curve (Fig. 4C) was found by a sigmoid model $\left(r^{2}=0.84\right)$.

Although depth profiles of total bacterial abundance and biomass changed seasonally in the lake (Fig. 5), the detection efficiencies of different morphotypes with probe EUB I-III confirmed our observations from May 2005. In addition, filaments had developed at some depths. On average, $54 \%$ (range: 41 to $72 \%$ ) of DAPI-stainable objects could be hybridized, corresponding to $80 \%$ (range: 62 to $98 \%$ ) of total biomass (Fig. 5). Total abundance and biomass increased above the sediment on all sampling dates.

From June 2005 to February 2006, we also determined the morphological composition and spatiotemporal dynamics of all DAPI-stainable objects and

Fig. 2. (A-C) Use of parameter restrictions allowing for the stepwise discrimination of bacterial morphotypes. Gray boxes indicate morphotypes already excluded from the stepwise detection. (A) Elongation: large rods were defined as cells with an Elongation $>2.3$ and a Circularity $<0.85$. (B) Circularity: vibrio-shaped cells were detected by the restriction Circularity $<0.7$. (C) MaxFeret: large cocci were defined by MaxFeret $>0.6 \mu \mathrm{m}$. Bars show the 25th, 50th, and 75th percentiles of all data; whiskers stand for the 10th and 90th percentiles; black circles indicate the 5th and 95th percentiles ( $\mathrm{n}=1200$ measured bacteria). Diamonds symbolize the arithmetic means. (D) Size frequency of all rod-shaped cells. Size distribution indicated a peak of small rods (average length $=0.55 \mu \mathrm{m}$ ) and a wide size range of larger rods 


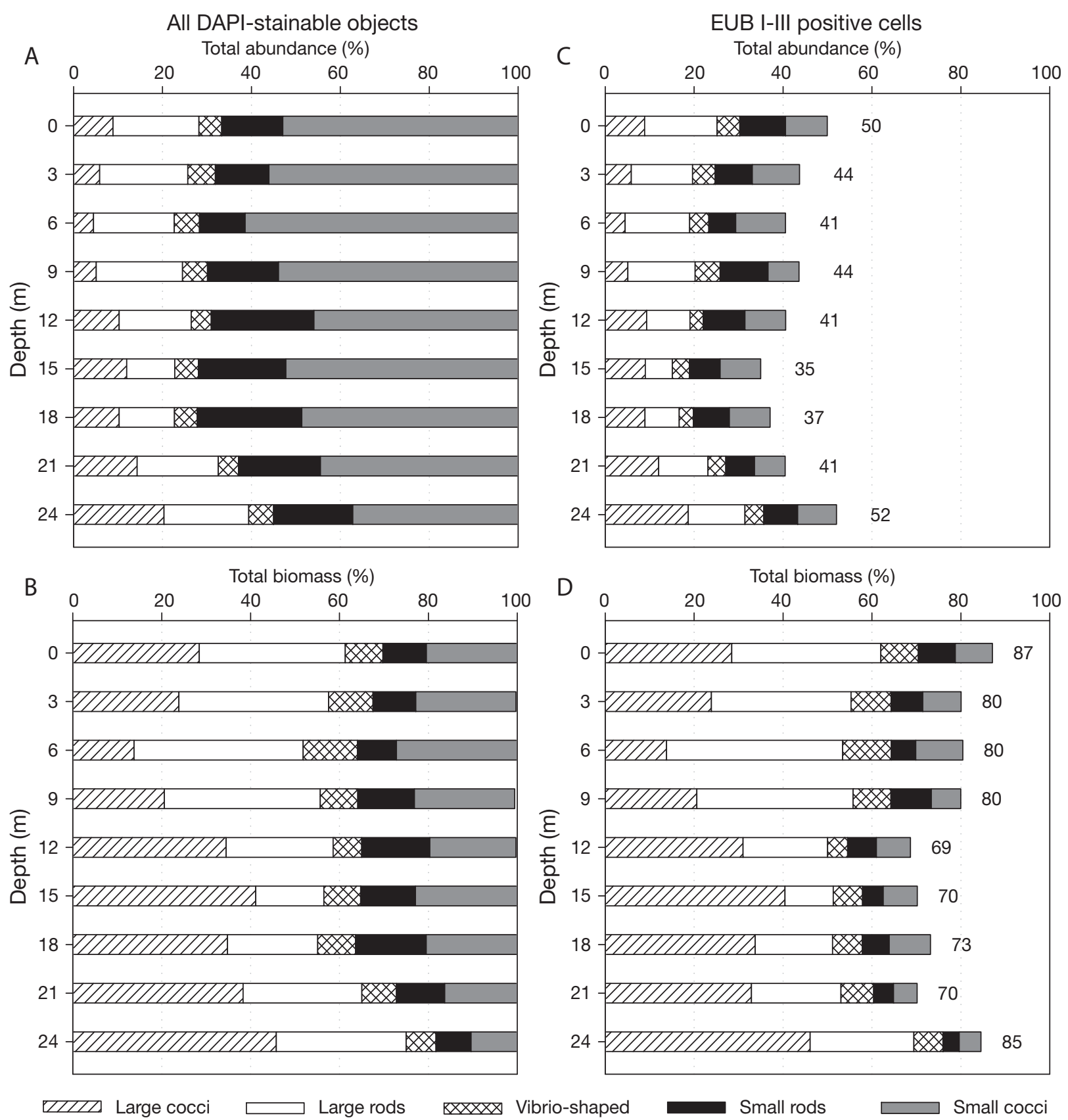

Fig. 3. Bacterioplankton in Piburger See in May 2005. Contribution (\%) of 5 different bacterial morphotypes to (A) total abundance and (B) biomass of DAPI-stainable objects $(=100 \%)$, and (C) to total abundance and (D) biomass of DAPI-stainable objects also hybridized with the oligonucleotide probe EUB I-III. The width of each column resembles the total EUB detection efficiency, given also as value beside each column (per each depth: $\mathrm{n}=800$ to 1200 DAPI-stainable objects, corresponding to 300 to 600 hybridized cells)

that of 3 broad phylogenetic lineages (Fig. 6, Table 3). Actinobacteria formed small morphotypes, mainly small rods (mean cell volume $=0.018 \mu \mathrm{m}^{3}$ ) and cocci $\left(0.028 \mathrm{~m}^{3}\right)$, and some larger rods with minimal cell widths and consequently low cell volumes $\left(0.024 \mathrm{\mu m}^{3}\right)$. We never observed filamentous morphotypes in this lineage (Table 3). In contrast, all filaments belonged to the Cytophaga-Flavobacterium-Bacteroides group, which also occurred mainly as large rods and cocci (Fig. 6, Table 3). A clear correspondence between morphology and taxonomic affiliation could not be observed for Betaproteobacteria. The morphological variability in this group was high, partly mirroring the morphotype dynamics of the total bacterioplankton 

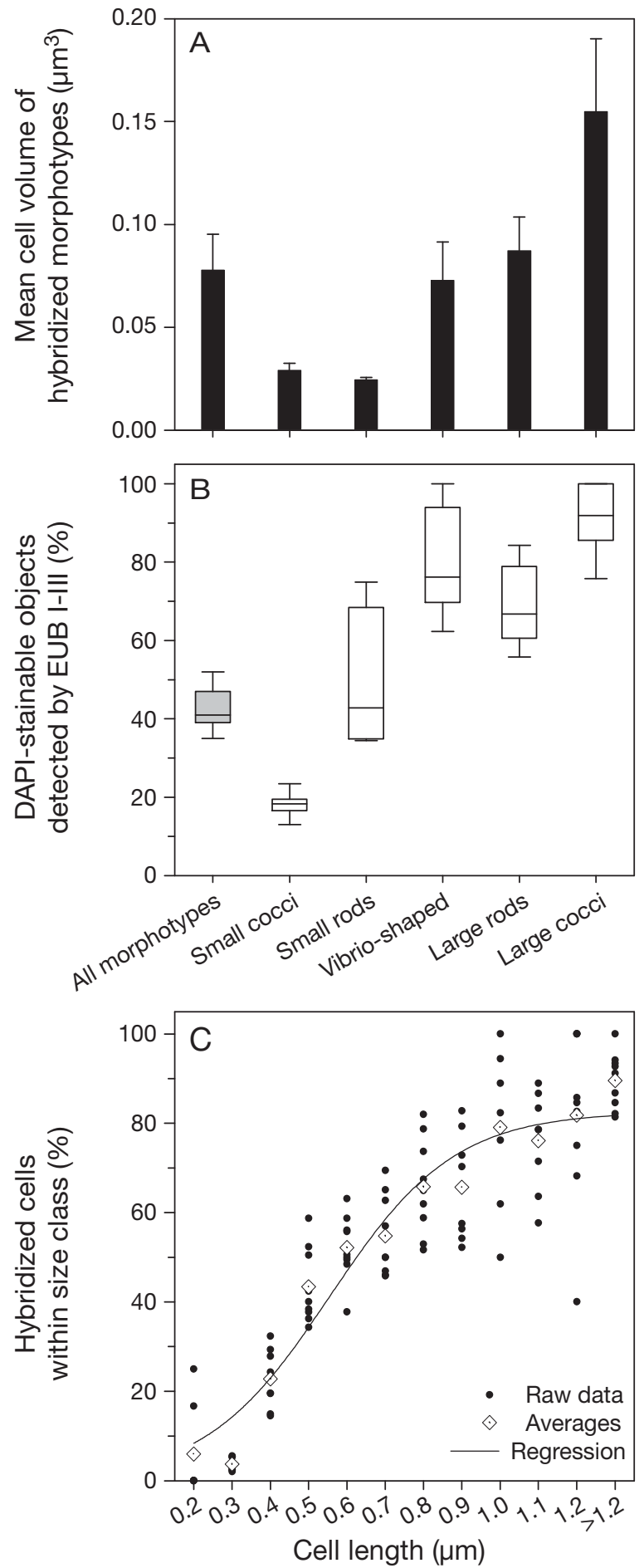

Fig. 4. Bacterioplankton in Piburger See in May 2005. (A) Mean cell volumes of EUB I-III hybridized morphotypes. (B) Detection frequency of different bacterial morphotypes by hybridization with the oligonucleotide probe EUB I-III. Bars show the 25th, 50th, and 75th percentiles of all data; whiskers stand for the 10th and 90th percentiles. (C) Relationship between bacterial cell length class and the fraction of hybridized bacteria contained therein. A sigmoid regression $\left(\mathrm{r}^{2}=0.84\right)$ determines the hybridized cells ( $y$-value) within a size class ( $x$-value): $y=83 /\left(1+\mathrm{e}^{(-(x-0.56) / 0.16)}\right)$
(Fig. 6). In the epilimnion, Betaproteobacteria occurred mainly as large rods and vibrioid cells, whereas in the hypolimnion, members of this lineage formed mainly small rods and cocci.

Due to the varying morphological composition and cell sizes of the 3 lineages, their contribution to the total bacterioplankton biomass differed from their numerical importance (Fig. 7). Although Actinobacteria were the most abundant group, with an average of $22 \%$ (range: 15 to $30 \%$ ) of DAPI-stainable objects, their contribution to the total biomass was minimal with $12 \%$ ( 3 to $21 \%$ ). The opposite was observed for Betaproteobacteria, making up $14 \%$ (5 to $28 \%$ ) of the total abundance and $24 \%$ (9 to $50 \%$ ) of the total biomass (Fig. 7). Even more pronounced, the Cytophaga-Flavobacterium-Bacteroides group represented only $6 \%$ ( 2 to $11 \%$ ) of the total abundance, but $27 \%$ (8 to $73 \%$ ) of the total biomass (Fig. 7 ).

\section{DISCUSSION}

\section{Methodological remarks}

Initial studies using FISH for analyzing freshwater systems were mainly based on Cy3-labeled oligonucleotide probes (see Table 1 in Bouvier \& del Giorgio 2003). The fluorescence properties of hybridized bacteria (especially with small morphologies) were hampered by the low intensities and fast fading of the fluorescence signals. The introduction of CARD-FISH solved most of these drawbacks, allowing the detection of even minute cells and yielding bright fluorescence signals for hybridized bacteria (Sekar et al. 2003, Amann \& Fuchs 2008). High hybridization efficiencies were usually found in manipulation experiments (e.g. size fractionations or nutrient enrichments) and were linked to the disproportional growth of distinct lineages with large cell sizes, e.g. Betaproteobacteria (Salcher et al. 2007 and references therein). Adequately high EUB-detection values were also reported for un-manipulated lake samples, even for the bacterioplankton of the ultra-oligotrophic high mountain lake Gossenköllesee (Alfreider et al. 1996, Pérez \& Sommaruga 2006). However, with an abundance of $10^{5} \mathrm{cells} \mathrm{ml}^{-1}$, the total bacterial assemblage of that lake was clearly dominated by larger morphotypes with cell volumes of 0.06 to $0.09 \mathrm{\mu m}^{3}$ (Pernthaler et al. 1997). Large rods, vibrio-shaped cells and filaments dominated, whereas small cocci and rods together represented only $20 \%$ of all DAPI-stainable objects (Posch et al. 1997, T. Posch unpubl. data.). Consequently, a positive correlation between the size of a bacterium and its probability to be hybridized was suggested (Pernthaler et al. 1997). Such a relationship seems to 

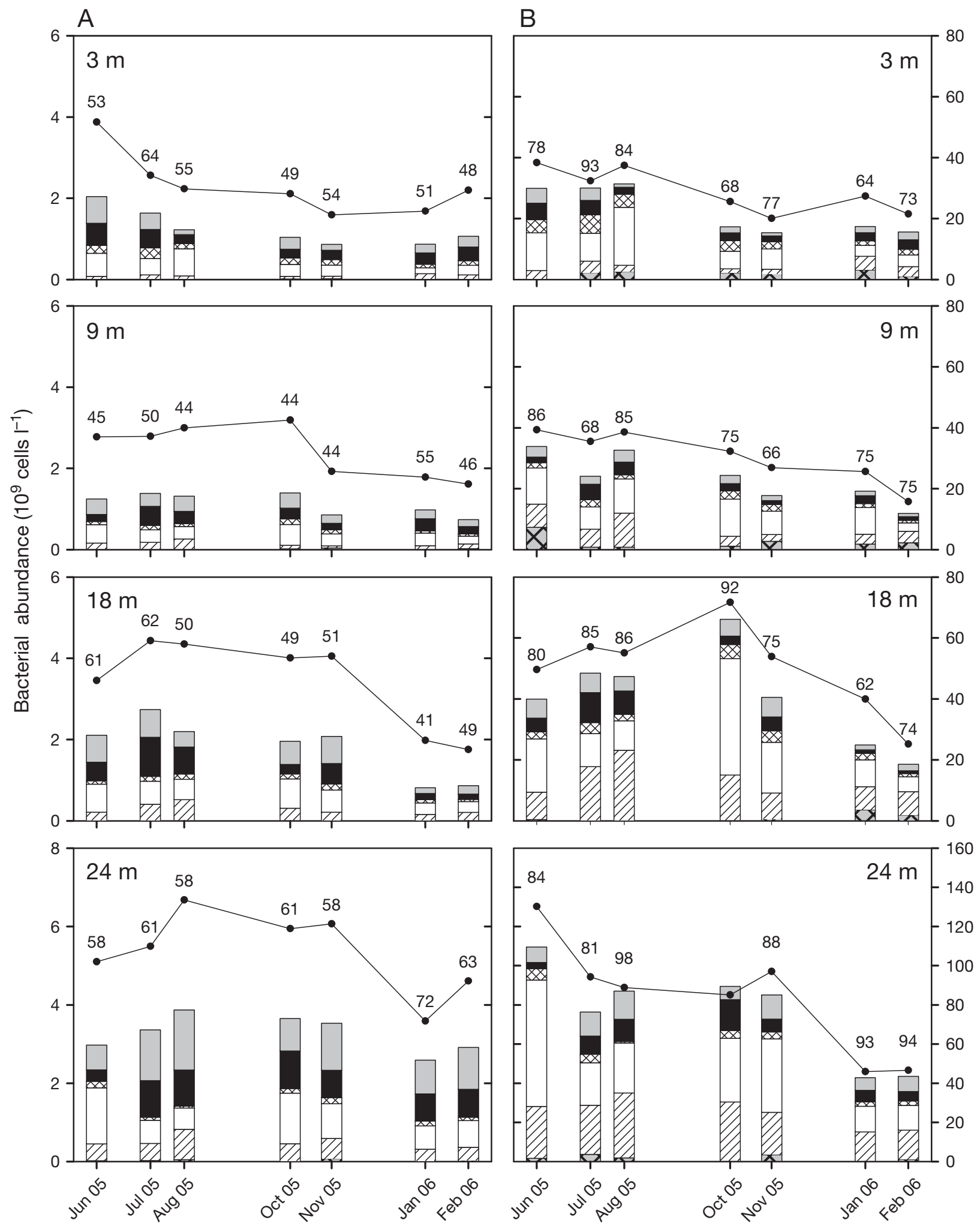

Small cocci

Small rods Vibrio-shaped

$\square$ Large rods $\boxminus$ Large cocci

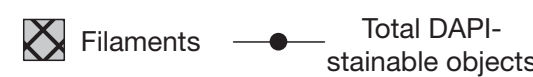

Fig. 5. Bacterioplankton in Piburger See in June 2005 to February 2006. Contribution of 6 different bacterial morphotypes hybridized with probe EUB I-III to (A) total number and (B) biomass of DAPI-stainable objects. Numbers above total values stand for the hybridization efficiency (in \%) of total DAPI-stainable objects 

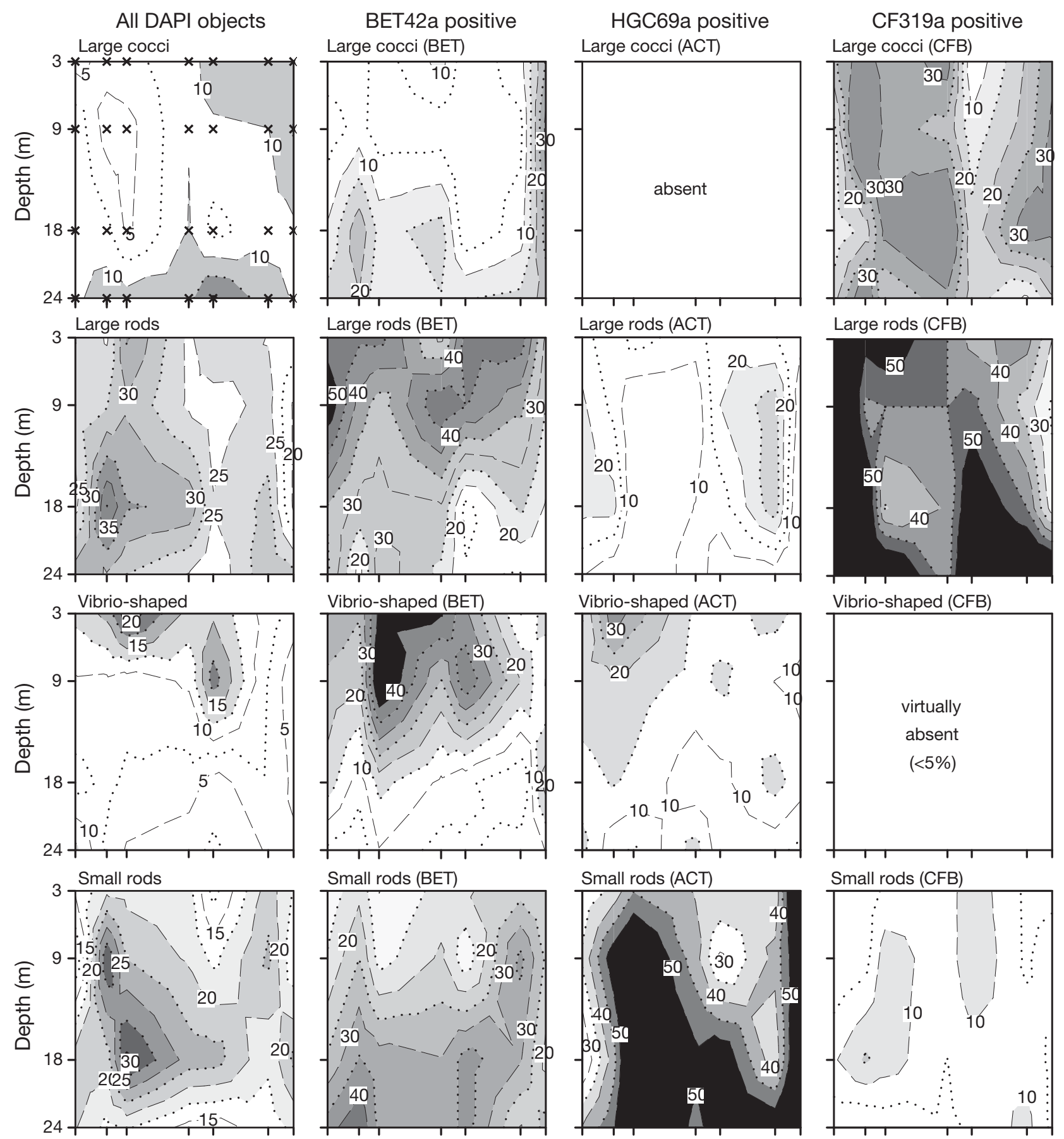

Vibrio-shaped (CFB)
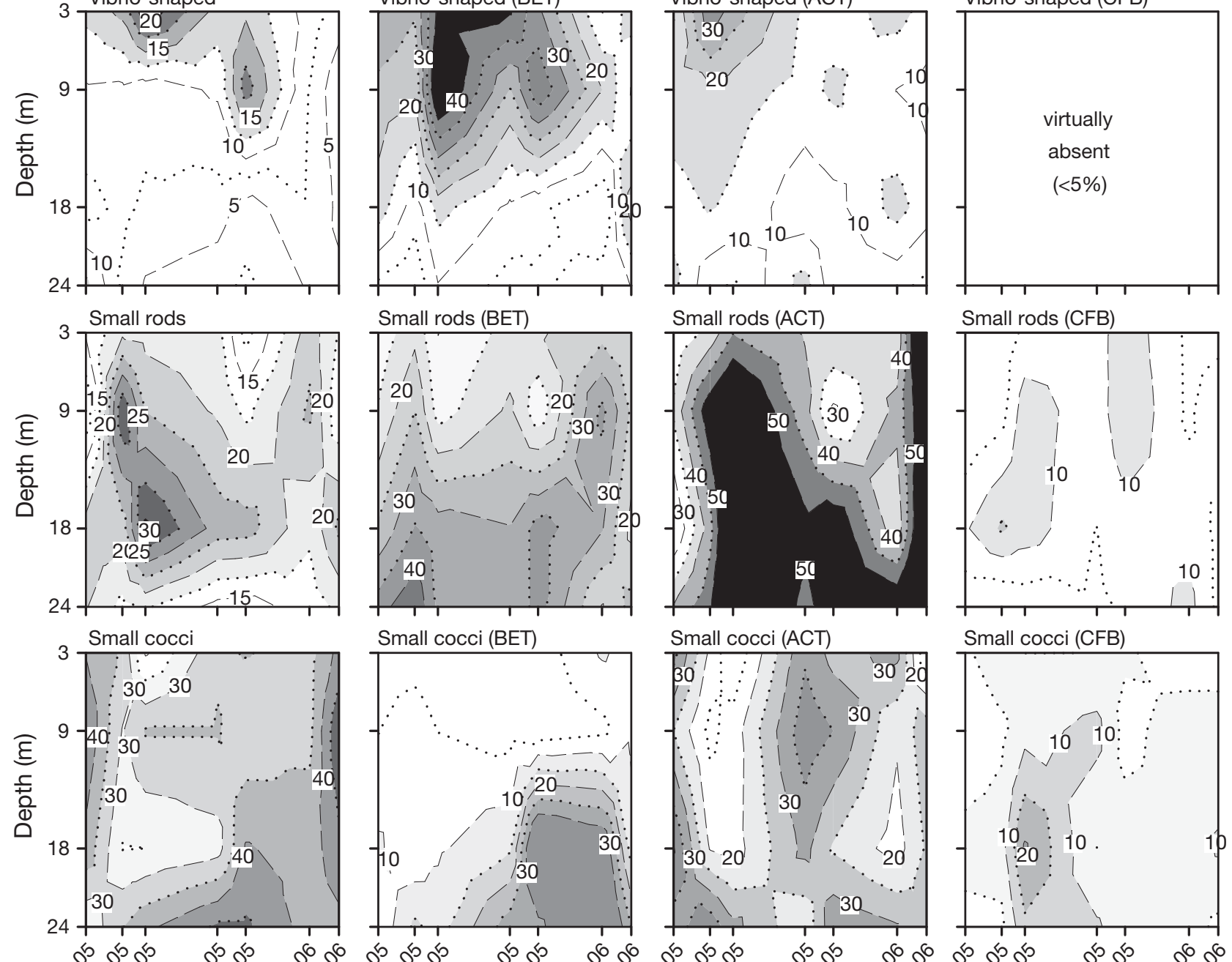

Small cocci (CFB)

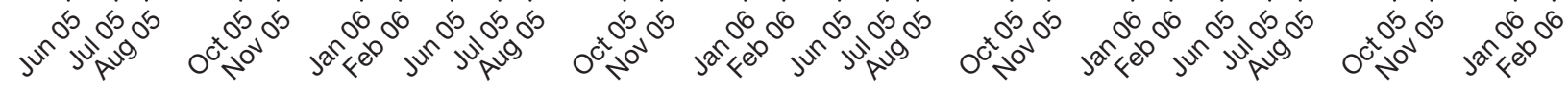


Table 3. Differences in relative abundances of morphotypes within individual phylogenetic groups analyzed by 2-way ANOVA and post-hoc pairwise comparisons (Scheffé method). Identical numbers indicate groups that are statistically indistinguishable. -1 = significantly lower percentage than group(s) $0 ;+1=$ significantly higher percentage than group(s) 0

\begin{tabular}{|lcccc|}
\hline & EUB I-III & BET42a & HGC69a & CF319a \\
\hline Small cocci & +1 & 0 & +1 & 0 \\
Small rods & 0 & 0 & +1 & -1 \\
Vibrio-shaped & 0 & 0 & 0 & -1 \\
Large rods & 0 & 0 & -1 & +1 \\
Large cocci & 0 & 0 & -1 & +1 \\
Filaments & 0 & 0 & 0 & +1 \\
\hline
\end{tabular}

be reasonable for monolabeled oligonucleotide probes. The cellular ribosome content is probably linked to cell size, and therefore hybridization efficiency would increase with cell dimensions. When applying CARDFISH this correlation should be less clear, as even a small number of bound probe molecules would result in strong signal amplification (Schönhuber et al. 1997). As recently shown by Hoshino et al. (2008), the minimum amount of 16S rRNA molecules needed to ensure a successful detection of Escherichia coli is 26 to 41 times lower with CARD-FISH than with conventional FISH.

Nevertheless, in the present study we found indications for a positive relationship between cell size and hybridization success, at least for the hybridization with probe EUB I-III (Fig. 4C). We found exceptions concerning different morphotypes, e.g. medium-sized vibrio-shaped bacteria showed much higher detection probabilities than expected (Fig. 4B). In addition, small rods were more efficiently detected than small cocci, although these 2 morphotypes had equivalent cell volumes (Fig. 4A). This could be an indication that the latter morphotype may harbor objects of nonbacterial origin.

We challenge DAPI staining as the standard method for the determination of in situ bacterial abundances in aquatic systems. Instead, FISH should be regarded as a more reliable method for Bacteria and Archaea. There is knowledge about the unspecific staining properties of DAPI (Bettarel et al. 2000, Zampino et al. 2004) and the determination of bacterial abundance is still affected by the subjectivity of each researcher. Our observation that most of the small particles (small cocci) were not hybridized reflects a long lasting
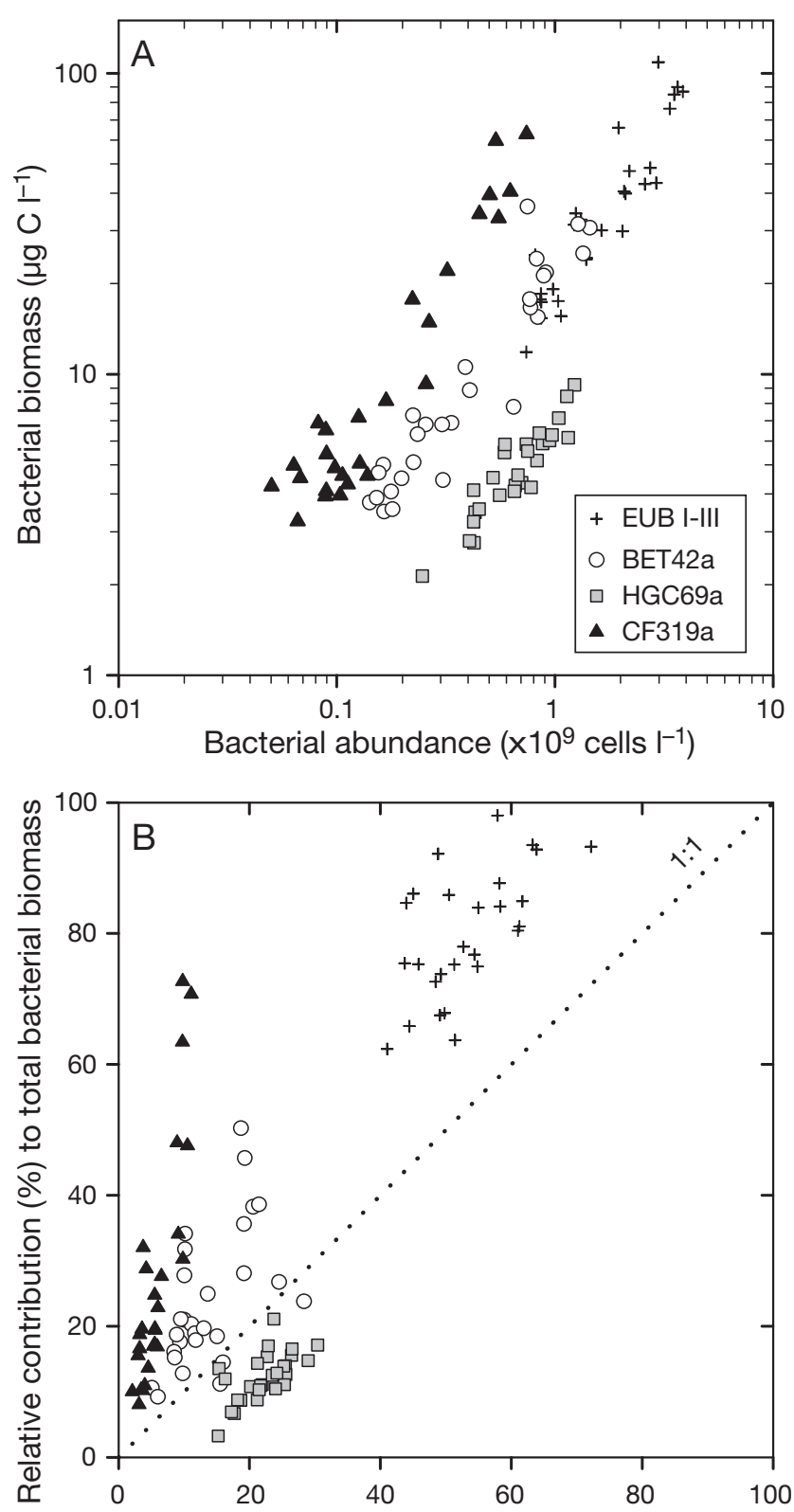

Relative contribution (\%) to total bacterial abundance

Fig. 7. Bacterioplankton in Piburger See in June 2005 to February 2006. (A) Abundance versus biomass for 3 bacterial lineages and all Bacteria. (B) Proportion of 3 lineages and all Bacteria to total bacterial abundance versus their proportions to total bacterial biomass (i.e. all DAPI-stainable objects)

( $>20$ yr) discussion. Since DAPI was accepted as the easiest way to determine bacterial abundances, the character of these minute dots is still unclear. Our work

Fig. 6. Bacterioplankton in Piburger See in June 2005 to February 2006. Spatio-temporal morphotype frequency dynamics (in \%) of all DAPI-stainable objects and 3 phylogenetic lineages. Bacteria were hybridized with the following oligonucleotide probes: BET42a for Betaproteobacteria (BET), HGC69a for Actinobacteria (ACT) and CF319a for the Cytophaga-FlavobacteriumBacteroides group (CFB). Sampling depths are indicated by ' $\mathrm{X}$ ' in the top left plot 
demonstrates that more than $80 \%$ of these particles were not recognized as Bacteria.

On the other hand, DAPI staining is needed for the measurement of bacterial dimensions. Several volumeto-carbon conversion factors are based on bacterial sizes determined from DAPI-stained preparations (Posch et al. 2001). In that comparative study, the allometric conversion factor published by Loferer-Krössbacher et al. (1998) was recommended for DAPIstained preparations. Specific conversion factors were also developed for acridine orange (AO)-stained bacteria (Posch et al. 2001), but AO is not used as a typical counterstain for FISH preparations. A direct measurement of cell sizes from CARD-FISH images would be possible, but it is hampered by strong halo-effects due to the signal amplification process via catalyzed reporter deposition (CARD). Additionally, there is no specific volume-to-carbon conversion factor available for bacterial cell sizes determined from CARD-FISH to this date.

In terms of cell counts, there is a need for fluorescent dyes other than DAPI in the future. Concerning volume-to-carbon conversion factors, DAPI has to be accepted as a usable stain at present.

\section{Significance of morphotypes}

Henrici (1933; Plate 1) already indicated the huge variety of bacterial morphotypes in lakes, criticizing that the isolation of freshwater bacteria on culture plates does not mirror the morphological variability in situ. As the quantification of bacterioplankton is mainly based on direct counting techniques, extensive knowledge of the ecological significance of different bacterial morphotypes would be expected. Moreover, several authors have presented sophisticated image analysis routines for an automated detection of bacterial morphotypes from various ecosystems (Blackburn et al. 1998, Liu et al. 2001, Daims et al. 2006). However, surprisingly few studies to date have reported on the morphotype composition of freshwater bacterioplankton (Schmaljohann et al. 1987, Fischer \& Velimirov $2000)$ and the seasonal succession of morphotypes (Kirschner \& Velimirov 1997, Jochem 2001). Some conspicuous morphotypes (filaments, prosthecate bacteria) have been studied in more detail, e.g. in the context of predation pressure by bacterivorous protists. Image analysis systems even allowed linking information on distinct larger morphotypes with cell-specific physiological activities such as the uptake of radiolabelled substrates (Cottrell \& Kirchman 2004, Nielsen et al. 2006) or phosphatase activity (Nedoma \& Vrba 2006). The latter authors described large differences in extracellular acid phosphatase activity for various mor- photypes. For example, a conspicuous vibrioid morphotype ( $5 \mu \mathrm{m}$ cell length) contributed only $4 \%$ to the total biomass but $31 \%$ to total bacterioplankton activity. In addition, smaller cells had a longer lag period before the labeled substrate was hydrolyzed, possibly indicating morphotype-specific activity kinetics. Morphotype-specific differences were also described for the reduction of 2-(p-iodophenyl)-3-(p-nitrophenyl)-5phenyl tetrazolium chloride (INT), a compound used to determine bacterial respiration (Posch et al. 1997). In that study, 2 to $5 \mu \mathrm{m}$ long rods and prosthecate bacteria showed fastest uptake kinetics, whereas smaller morphotypes and filaments larger than $10 \mu \mathrm{m}$ required a much longer incubation time for the reduction of INT. Altogether, there are indications that specific morphotypes may differ not only in their shape but also in their physiological activities. Nevertheless, the functional role of less conspicuous morphotypes, e.g. small cocci, rods and minute vibrio-shaped bacteria, is still poorly investigated, although these forms can dominate freshwater bacterioplankton.

Striking ideas about the ecological and evolutionary significance of bacterial cell morphology are explored in the review of Young (2006). The author lists multiple examples of how bacterial morphology can be linked to nutrient access, the bacterial cell cycle, attachment, motility, and predation. Currently, most observations are still based on lab experiments with isolated bacteria. Single or multiple nutrient limitations can strongly affect the morphological variability of single strains, e.g. of Vibrio sp. (Holmquist \& Kjelleberg 1993, Løvdal et al. 2007) or Caulobacter sp. (Poindexter 1984). Regarding field studies, it seems that our knowledge is still restricted to how grazing pressure, and especially nutrient limitation, influences the in situ composition of less conspicuous bacterial morphotypes and their activities (Thingstad et al. 2005). In this context, the high surface-to-volume ratios of small thin rods and vibrio-shaped cells (Young 2006) could be regarded as one adaptive strategy to low nutrient concentrations in freshwater systems.

\section{Morphotypes and biomass of specific lineages}

The measurement of cell size and shape of bacteria from different phylogenetic populations is a prerequisite for obtaining a more detailed picture of biomass, production and carbon fluxes in microbial food webs (Yokokawa et al. 2004, Zhang et al. 2006). As shown by Posch et al. (2007) and Salcher et al. (2007), a single phylogenetic lineage, although present at low abundance, can majorly contribute to the total bacterial biomass in Piburger See. A striking example for this discrepancy was described for the so-called filamentous 
SOL morphotype (Schauer \& Hahn 2005). This monophyletic cluster in the family Saprospiraceae (Sphingobacteria) accounted for $<1$ to $4.5 \%$ of total bacterial abundances, but contributed up to $45 \%$ to total bacterial biovolumes in different freshwater systems. In all systems studied, Schauer \& Hahn (2005) could not find any other than the same filamentous morphology for this cluster. Kirchman et al. (2003) found mean cell volumes for the DE (Delaware Estuary) cluster 2 of Cytophaga-like bacteria that were 2 times larger than those determined for other bacteria. Thus, bacteria of this cluster contributed more to total bacterial biomass than indicated by their abundance. Most likely, the numerical standing stock of some bacterial lineages will not reflect their biomass, biomass production or activity status (Cottrell \& Kirchman 2003, Horňák et al. 2006). For the evaluation of lineage-specific biomass, we believe that the image analysis technique presented here is powerful. Although we used probes covering very broad phylogenetic branches, we found some consistency concerning morphotype versus phylotype for at least 2 bacterial groups, e.g. Actinobacteria were predominately small rods, cocci and vibrios (Fig. 6) whereas Cytophaga formed only large morphotypes. Such clear patterns were not observed for the seasonality of Betaproteobacteria, which exhibited a high morphological variability, possibly reflecting a high phylogenetic or growth status diversity within this group (Salcher et al. 2008). Based on the methodological approach presented here, it will be worth looking for the environmental variables that lead to different morphotypes of distinct aquatic bacterial lineages in future studies. It will be fascinating to learn more about the evolutionary advantages that distinct bacterial shapes may harbor.

Acknowledgements. This study was funded by the Austrian Science Fund (FWF P17554-B06) and the Swiss National Science Foundation (SNF 3100A0-117765). We thank Jakob Pernthaler and Michael Zeder for their critical and helpful comments. We thank Stefan Andreatta for his help during the development of the software. We appreciate that Kristina Hamilton converted our Austrian-Swiss-English to a real language. Finally, we thank Kevin D. Young (2006) for his excellent comment which inspired us to write this manuscript: 'To be brutally honest, few people care that bacteria have different shapes. Which is a shame, because the bacteria seem to care very much.'

\section{LITERATURE CITED}

Alfreider A, Pernthaler J, Amann R, Sattler B, Glöckner FO, Wille A, Psenner R (1996) Community analysis of the bacterial assemblages in the winter cover and pelagic layers of a high mountain lake by in situ hybridization. Appl Environ Microbiol 62:2138-2144

Amann R, Fuchs B (2008) Single-cell identification in microbial communities by improved fluorescence in situ hybridization techniques. Nat Rev Microbiol 6:339-348

Bettarel Y, Sime-Ngando T, Amblard C, Laveran H (2000) A comparison of methods for counting viruses in aquatic systems. Appl Environ Microbiol 66:2283-2289

> Blackburn N, Hagström ̊., Wikner J, Cuadros-Hansson R, Bjørnsen PK (1998) Rapid determination of bacterial abundance, biovolume, morphology, and growth by neural network-based image analysis. Appl Environ Microbiol 64:3246-3255

Bouvier T, del Giorgio PA (2003) Factors influencing the detection of bacterial cells using fluorescence in situ hybridization (FISH): a quantitative review of published reports. FEMS Microbiol Ecol 44:3-15

Cottrell MT, Kirchman DL (2003) Contribution of major bacterial groups to bacterial biomass production (thymidine and leucine incorporation) in the Delaware estuary. Limnol Oceanogr 48:168-178

Cottrell MT, Kirchman DL (2004) Single-cell analysis of bacterial growth, cell size, and community structure in the Delaware estuary. Aquat Microb Ecol 34:139-149

Daims H, Bruhl A, Amann R, Schleifer KH, Wagner M (1999) The domain-specific probe EUB338 is insufficient for the detection of all Bacteria: development and evaluation of a more comprehensive probe set. Syst Appl Microbiol 22: 434-444

Daims H, Lücker S, Wagner M (2006) daime, a novel image analysis program for microbial ecology and biofilm research. Environ Microbiol 8:200-213

Fischer UR, Velimirov B (2000) Comparative study of the abundance of various bacterial morphotypes in a eutrophic freshwater environment determined by AODC and TEM. J Microbiol Methods 39:213-224

Henrici AT (1933) Studies of freshwater bacteria (I. A direct microscopic technique). J Bacteriol 25:277-287

Hicks RE, Amann R, Stahl DA (1992) Dual staining of natural bacterioplankton with 4',6'-diamidino-2-phenylindole and fluorescent oligonucleotide probes targeting kingdom-level 16S rRNA sequences. Appl Environ Microbiol 58:2158-2163

Holmquist L, Kjelleberg S (1993) Changes in viability, respiratory activity and morphology of the marine Vibrio sp. strain S14 during starvation of individual nutrients and subsequent recovery. FEMS Microbiol Ecol 12:215-224

> Horňák K, Jezbera J, Nedoma J, Gasol J, Šimek K (2006) Effects of resource availability and bacterivory on leucine incorporation in different groups of freshwater bacterioplankton, assessed using microautoradiography. Aquat Microb Ecol 45:277-289

Hoshino T, Yilmaz S, Noguera D, Daims H, Wagner M (2008) Quantification of target molecules needed to detect microorganisms by fluorescence in situ hybridization (FISH) and catalyzed reporter deposition-FISH. Appl Environ Microbiol 74:5068-5077

> Jochem FJ (2001) Morphology and DNA content of bacterioplankton in the northern Gulf of Mexico: analysis by epifluorescence microscopy and flow cytometry. Aquat Microb Ecol 25:179-194

Kirchman DL, Yu L, Cottrell MT (2003) Diversity and abundance of uncultured Cytophaga-like bacteria in the Delaware Estuary. Appl Environ Microbiol 69:6587-6596

> Kirschner AKT, Velimirov B (1997) A seasonal study of bacterial community succession in a temperate backwater system, indicated by variation in morphotype numbers, biomass, and secondary production. Microb Ecol 34:27-38

> Lee N, Nielsen PH, Andreasen KH, Juretschko S, Nielsen JL, Schleifer KH, Wagner M (1999) Combination of fluorescent in situ hybridization and microautoradiography - a 
new tool for structure-function analyses in microbial ecology. Appl Environ Microbiol 65:1289-1297

Liu J, Dazzo FB, Glagoleva O, Yu B, Jain AK (2001) CMEIAS: A computer-aided system for the image analysis of bacterial morphotypes in microbial communities. Microb Ecol 41:173-194

Loferer-Krössbacher M, Klima J, Psenner R (1998) Determination of bacterial cell dry mass by transmission electron microscopy and densitometric image analysis. Appl Environ Microbiol 64:688-694

Løvdal T, Skjoldal E, Heldal M, Norland S, Thingstad T (2007) Changes in morphology and elemental composition of Vibrio splendidus along a gradient from carbon-limited to phosphate-limited growth. Microb Ecol 55:152-161

Manz W, Amann R, Ludwig W, Wagner M, Schleifer KH (1992) Phylogenetic oligodeoxynucleotide probes for the major subclasses of Proteobacteria: problems and solutions. Syst Appl Microbiol 15:593-600

Manz W, Amann R, Ludwig W, Vancanneyt M, Schleifer KH (1996) Application of a suite of 16S rRNA-specific oligonucleotide probes designed to investigate bacteria of the phylum Cytophaga-Flavobacter-Bacteroides in the natural environment. Microbiology 142:1097-1106

Nedoma J, Vrba J (2006) Specific activity of cell-surface acid phosphatase in different bacterioplankton morphotypes in an acidified mountain lake. Environ Microbiol 8: 1271-1279

Nielsen JL, Klausen C, Nielsen PH, Burford M, Jörgensen NOG (2006) Detection of activity among uncultured Actinobacteria in a drinking water reservoir. FEMS Microbiol Ecol 55:432-438

Pérez MT, Sommaruga R (2006) Differential effect of algaland soil-derived dissolved organic matter on alpine lake bacterial community composition and activity. Limnol Oceanogr 51:2527-2537

Pernthaler J, Alfreider A, Posch T, Andreatta S, Psenner R (1997) In situ classification and image cytometry of pelagic bacteria from a high mountain lake (Gossenköllesee, Austria). Appl Environ Microbiol 63:4778-4783

Pernthaler J, Pernthaler A, Amann R (2003) Automated enumeration of groups of marine picoplankton after fluorescence in situ hybridization. Appl Environ Microbiol 69: 2631-2637

Poindexter JS (1984) The role of calcium in stalk development and in phosphate acquisition in Caulobacter crescentus. Arch Microbiol 138:140-152

Porter KG, Feig YS (1980) The use of DAPI for identifying and counting aquatic microflora. Limnol Oceanogr 25:943-948

Posch T, Pernthaler J, Alfreider A, Psenner R (1997) Cell-specific respiratory activity of aquatic bacteria studied with the Tetrazolium reduction method, Cyto-Clear slides, and image analysis. Appl Environ Microbiol 63:867-873

Posch T, Loferer-Krössbacher M, Gao G, Alfreider A, Pernthaler J, Psenner R (2001) Precision of bacterioplankton biomass determination: a comparison of two fluorescent dyes, and of allometric and linear volume-to-carbon conversion factors. Aquat Microb Ecol 25:55-63

Posch T, Mindl B, Horňák K, Jezbera J and others (2007) Bio-

Editorial responsibility: Klaus Jürgens,

Rostock, Germany mass reallocation within freshwater bacterioplankton induced by manipulating phosphorus availability and grazing. Aquat Microb Ecol 49:223-232

Roller C, Wagner M, Amann R, Ludwig W, Schleifer KH (1994) In situ probing of gram-positive bacteria with high DNA G+C content using 23S rRNA-targeted oligonucleotides. Microbiology 140:2849-2858

Salcher MM, Hofer J, Horňák K, Jezbera J and others (2007) Modulation of microbial predator-prey dynamics by phosphorus availability: growth patterns and survival strategies of bacterial phylogenetic clades. FEMS Microbiol Ecol 60:40-50

Salcher MM, Pernthaler J, Zeder M, Psenner R, Posch T (2008) Spatio-temporal niche separation of planktonic Betaproteobacteria in an oligo-mesotrophic lake. Environ Microbiol 10:2074-2086

Schauer M, Hahn M (2005) Diversity and phylogenetic affiliations of morphologically conspicuous large filamentous bacteria occurring in the pelagic zones of a broad spectrum of freshwater habitats. Appl Environ Microbiol 71:1931-1940

Schmaljohann R, Pollingher U, Berman T (1987) Natural populations of bacteria in Lake Kinneret: observations with scanning electron and epifluorescence microscopy. Microb Ecol 13:1-12

Schönhuber W, Fuchs B, Juretschko S, Amann R (1997) Improved sensitivity of whole-cell hybridization by the combination of horseradish peroxidase-labeled oligonucleotides and tyramide signal amplification. Appl Environ Microbiol 63:3268-3273

> Sekar R, Pernthaler A, Pernthaler J, Warnecke F, Posch T, Amann R (2003) An improved protocol for the quantification of freshwater Actinobacteria by fluorescence in situ hybridization. Appl Environ Microbiol 69:2928-2935

Thingstad TF, Øvreås L, Egge JK, Løvdal T, Heldal M (2005) Use of non-limiting substrates to increase size; a generic strategy to simultaneously optimize uptake and minimize predation in pelagic osmotrophs? Ecol Lett 8:675-682

> Wagner M, Horn M, Daims H (2003) Fluorescence in situ hybridisation for the identification and characterisation of prokaryotes. Curr Opin Microbiol 6:302-309

Wu QL, Zwart G, Schauer M, Kamst-van Agterveld MP, Hahn MW (2006) Bacterioplankton community composition along a salinity gradient of sixteen high-mountain lakes located on the Tibetan Plateau, China. Appl Environ Microbiol 72:5478-5485

Yokokawa T, Nagata T, Cottrell MT, Kirchman DL (2004) Growth rate of the major phylogenetic bacterial groups in the Delaware estuary. Limnol Oceanogr 49:1620-1629

Young KD (2006) The selective value of bacterial shape. Microbiol Mol Biol Rev 70:660-703

Zampino D, Zaccone R, La Ferla R (2004) Determination of living and active bacterioplankton: a comparison of methods. Chem Ecol 20:411-422

Zhang Y, Jiao N, Cottrell MT, Kirchman DL (2006) Contribution of major bacterial groups to bacterial biomass production along a salinity gradient in the South China Sea. Aquat Microb Ecol 43:233-241

Submitted: September 2, 2008; Accepted: November 24, 2008 Proofs received from author(s): January 23, 2009 